\section{THE MONOCOTYLEDON THE UNIVERSAL} TYPE OF SEEDS*

$1 \mathrm{~T}$ must be evident to those who heard my paper on "Adnation in Coniferr" at the Chicago meeting of the Association that the otservations there retailed could scarcely be accounter for, if the belief be true which is generally held by botanists, that the leaf originates at the node from which it seems to spring. It is not, however, an object with me to attack existing theories, or establish new ones, but simply to present facts as I see them. The origin of the leaf will no doubt prove a question which will in time take care of itself. But this generalisation cannot be avoided by the readers of that paper, that the whole plant is originally a unity; and that the subsequent formation of elementary organs, and their complete development, or absorption into one another, is the result of varying phases of nutrition. The leaves in Coniferæe were found to be free or united with the stem in proportion to the vigour of the central axis. Following up the subject, I now offer some facts which will show that all seeds are primarily monocotyledonous; and that division is a subsequent act, depending on circumstances which do not exist at the first commencement of the seed growth.

It is well known that in some species of Coniferous plants the number of cotyledons varies. I have noticed in addition to this that whether the cotyledons are few or many, there is no increase in the whole cotyledonous mass. In the Norway spruce, Abies excelsa, there are sometimes as many as ten cotyledons, in others only two. In the latter case they are broad and ovate, while in the furmer they are narrow and hair-like; in short, when in the two cotyledoned state it is not possible to note any difference between a seedling Norway spruce and a Chinese arbor vitæe, Biota orientalis, except by the lighter shade of green. The twoleaved condition is not common, but specimens of threes and others I exhibited to Drs. Torrey and Gray at the Troy meeting. Any one who will examine sprouting seeds of the Norway spruce will agree to the proposition that the cotyledons are not original and separate creations, but a divided unity. My next observations were on some acorns of Quercus agrifolia, the division into cotyledons were numerous and irregular. Cut across vertically, some represented the letter $C$, others the letter $N$, and again, with four cotyledons the letter $M$. Here again it was clear that whatever the form and number of the cotyledons, there was no increase of the original cotyledon mass. Examining sprouting peach kernels, the variations in form and number were of the most remarkable character. I need not repeat them in detail here, as they are reported in the April and May "Proceedings of the Academy of Natural Sciences of Philadelphia." In addition to the fact of no increase in the whole cotyledon mass, it was here clear that when the cotyledons were duplicated, the duplications at least were subsequent to the original ones. Still so far nothing had been seen to indicate when the first pair of cotyledons were formed. Ouercus macrocarpa and Quercus palustris were silent to my questions. In a large number I found no variations whatever. Each mass was divided smoothly and exactly into two cotyledons. Quercus robur, the English oak, however, gave some curious evidence. Two germs under one seed coat were numerous, and often three, and the cotyledons took on a variety of forms. But there was never any more increase in the cotyledonous mass than if but two lobes had been formed, and there was no more rule in the division than there would be in the sudden breakage of a piece of glass. A detailed account of these will also be found in the "Proceedings of the Academy of Natural Sciences of Philadelphia" for May. Quercus rubra, the American red oak, furnished the one link wanting to connect the first division into lobes with the other phenomena. All the acorns examined had three or four sutures in the cotyledon mass, and extending all along the longitudinal surface externally, without any reference to cotyledonal divisions. These sutures extended sometimes but a line in depth, at others almost to the centre of the mass, always accompanied by the inner membrane, as is the case in ruminated seeds. The whole mass was divided only in two parts in any that I examined of this species, but the division was always in the direction of the sutures. Hence each cotyledon was very irregular. Sometimes one-third the mass only went to one while the other had two-thirds of the whole mass. It was easier to burst in the weaker line of resistance. But the interest for us is to note that ordinarily the coty-

* Abstract of a Paper read at the Indianopolis Meeting of the American Association for the Advancement of Science, Augu ledonous mass was a unit-then the sutures or fissures were formed, and ultimately the two divisions of the lobes followed in their direction. The division was the last condition, not the first. I know how much we should guard against generalising on a limited supply of facts, but it requires an effort to believe that oaks, pines, and peaches, as we have seen primordially monocotyledons, are in this respect different from other so-called dicotyledonous plants; and if we grant that all seeds are primarily monocotyledonous, may we not ask why in any case they are divided? We have seen that there is no increase of mass in the division, the same amount is furnished in one as in many. Would it in any way injure the Indian corn to have its mass divided into two lobes? or would not the plantlet be as well provided for if the acorn were in one solid mass? Division would seem to be a necessity occurring subsequent to organisation, and existing from the position of the plumule alone. In monocotyledons, as we know, the plumule is directed parallel to, or away from, the coty. ledonous mass, when, of course, on this theory, it remains an undivided mass. But in the dicotyledonous section, the plumule is directed towards the apex of the mass; and as we know in the case of roots against stone walls, or nushrooms under pavingstones, the disposition in the growing force of plants is to go right forward, turning neither to the right nor the left; so in this mass of matter the development of the germ would make easy work of the division; and no doubt often at so early a stage as to give the impression we have been under hitherto, that the division is a primary and esseniial process.

\section{SCIENTIFIC SERIALS}

The Monthly Microscopical Foumal, No. 35, November 1871 . "On the Form and Use of the Facial Arches," by W. Parker, F.R.S., is chiefly occupied by observations on embryo salmon. "Amother Hint on Selecting and Mounting Diatoms," by Capt. Fred. H. Lang, details the method employed by the author for remounting diatoms, either previously badly mounted, or from which it is desirable to select certain forms. - "The Monad's Place in Nature," by Metcalfe Johnson, M.R.C.S.E., has for its object to show a connection between the earlier forms called Monads, and those higher and more complicated organisms at present recognised under the name of Infusoria, Mucedinæ, Conferve, Oscillatorix, \&c. The conclusions deduced from some of the experiments are that the author looks upon Monas in its earliest forms to be the starting point whence several products may result, and among the number are Infusoria, Mucedine, Englenr, Oscillatoriz. $\mathrm{He}$ is induced to believe that the Pinpoint Monad, when developed under absence of light and only a limited quantity of air, gives rise to the class of plants known as Mucedinæ. Again, he maintains that during the watching of the liquids under experiment the Monads presented various forms, evidently transitional, from the round Pin-head Monad to oval young Paramocia, until we come to sufficient size to give it a name such as Kolpoda Cucullus, \&c. - "Infusorial Circuit of Generations," by Theod. C. Hilgard, deals with a similar subject, but in a very different style. It is often very difficult to gather the author's meaning from language such as the following :"And from each little dot in these 'clouds of life' a separate vorticella can be seen to develop! It is here, indeed, at this first visible advent or exordium of animate life, and the resurrection of millions of germs through the spontaneous dissolution of a single one, that the last nubecular microscopic perceptions closely resemble the last nebular telescopic as well as the theoretic ones of Laplace's cosmogony." The concluding portion of this paper, which is reprinted from Silliman's Fournal, appears in the succeeding number, and is interesting as a contribution to the "curiosities of scientific literature."

THE Monthly Microscopical Fournal, No. 36, December 1871 . - "Notes of Prof. James Clark's Flagellate Infusoria, with Descriptions of New Species," by W. Saville Kent, F.Z.S. An entirely technical paper, consisting of the diagnostic characters of new species, with those of previously-described ones amended. Eleven forms are figured and described, all of which were found in fresh water at Stoke Newington.--"On Bog Mosses," by R. Braithwaite, M.D., F.L.S., Part II., is occupied chiefly with the anatomy of the leaf and development of the plant.- "On the Conjugation of Amœba," by J. G. Tatem, is a note serving to strengthen the supposition previously advanced by this author, "that these large Amœbæ so frequently met with in the autumn months are actually the incorporation of two individuals in a 
copulative act," from which free-swimming ciliated germs might eventually issue. "On the Connection of Nerves and Chromoblasts," by M. Georges Pouchet. The inference drawn from an examination of the pectoral fin of a young flat-fish is that there is a reality of connection between the nervous and sarcodic elements, but that the nature of this connection is unknown.

THE Rezue Scientifigue, Nos. 19-25, contains, among others, the following articles, translations, and reprints :-General Morin's eulogy on Piobert and his inventions in artillery; Dr. Carpenter's lectures at the Royal Institution; the continuation of Grehant's course of lectures on Experimental Physiology; M. Lorain on primary and secondary instruction in France; Berthelot on the union of alcohols with bases, and on the history of carbon; Moleschott on the regulators of human life; Saussiure on the life and works of Claparede;. Valentin on the electric properties of nerves during embryonic life, and during putrid decomposition; a summary of the most important papers read at the Bologna International Congress of Anthropology and Prehistoric Archreology; Contejean on the origin of sedimentary deposits; Mr. Bentham's last anniversary address to the Linnean Society : Fonvielle on aërial navigation ; Prof. Huxley's article in the Contemporary Revieze on English Critics of Darwin.

THE twentieth volume (1870) of the Verhandlungen der k.R. oologisch-botanischen Gesellschaft in Wien, although a stout ostavo, is hardly equal in bulk or in the variety of its contents to sone of its predecessors; nevertheless its readers will find in it an abundant supply of valuable papers on zoological and botanical subjects. As usual, entomological articles are in the majority under the former head, and here Dr. Winnertz leads off with two papers on Diptera, containing descriptions of species belonging to the Lestremine, a sub-family of Cecidomyida, and of the species of Heteropeza and Miastor-wtwo genera of the same family. Singularly enough these, and a shott notice by $M$. von Bergenstamm on the metamorphoses of Platypeza holosericea, are the only papers on Diptera in the volume. - The Lepidoptera also receive but little notice, but on the Rhynchota we have some important papers :--M. P. M. V. Gredier furnishes a list, with notes, of the Heteropterous Rhynchota of the Tyrol, and Dr. $\vec{F}$. $\mathrm{X}$ Fieber the characters of twelve new genera and twelve new species of the same group. The forms described by the latter are from various pirts of Southern Europe.--M. C. Tschek describes a number of Austrian Ichneumonidxe belonging to the grine of the Cryptoides, Dr. G. Mayr a number of new species of ants, and Dr. J. Kriechbaumer four new South European species of humble bees. - A paper on the Orthoptera of the Syrnian valley in Hungary by M. V. Graber, which includes an interesting description of the district, is the only other entomological paper to which we shall refer. - The malacologist will find a list of the land and freshwater mollusca of Galicia by Dr J. Jachno, a monograph of the genera Emmerida and Fossa1.ulues by M. Brusina, and an important paper on the anatomy of Tribonothonus and Philonycus - two forms of naked Pulmonata whilst for the ichthyologist we have the first part of a descriptive synopsis of the fishes of the Red Sea from Dr. C. B. Klunzinger, who also notices the animals observed upon a coral reef in the Red Sea. - M. D. Dybowski describes a new form of Salamander from Siberia under the name of Salanandrella Keyserlingiz, and Dr. Burmeister gives a description of the pelvis of Megatherium. The botanical papers are to a considerable extent of the nature of local lists, but some of these contain a good deal of descriptive matter. Thus in M. Schulzer von Müggenburg's "Mycological Observations in North Hungary" we find many descriptions of fungi; Glowacki and Arnold's "Lichens from Carniolia" contains descriptions of species, as does also the latter's "Lichenological Excursion into the Tyrol," and the contribution to the moss. flora of East by MM. Juratzka and Milde. M. F. Hazslinsky describes the Sphorize which are parasitic upon the rose; M. Julius Klein's mycological communications contain a description of a new genus of Mucorine fungi, and of some other forms which grew with its representative; and $M$. Schulzer von Müggenburg, abovementioned, has also his mycological contributions, which consist almost entirely of descriptive matter. The papers which treat of the higher forms of plants, and those describing the natural history journeys of their authors, are not numerous. We may mention especially a long paper by M. F. Krasan on the periodical phenomena of vegetable life, and an article by Dr. peration of the scales of the fruit in Ceratozamia mexicana. This list of papers will be sufficient to show how much there is in the proceedings of the Vienna Zoologico-Botanical Society to interest both the zoologist and the botanist.

\section{SOCIETIES AND ACADEMIES}

\section{LONDON}

Geological Society, December 6.-Mr. J. Prestwich, president, in the chair. Prof. Giovanni Capellini, of Bologna, was elected a Foreign Correspondent of the Society. x. "On the presence of a raised beach on Portsdown Hill, near Portsmouth, and on the occurrence of a Flint Implement at Downton." By Mr. Joseph Prestwich, F.R.S., President. The anthor noticed a section observed by him in a pit ten miles westward of Bourne Common and five miles inland in a lane on the north side of East Cams Wood. It is situated at an elevation of 300 feet above the sea.level, and shows some laminated sands wilh seams of shingle, overlying coarse flint-shingle with a few whole fints, which the author regarded as a westward continuation of the old sea-beach which has been traced from Brighton, past Chichester, to Boulne Common. A flint flake was found by the author at the bottom of the superficial soil in this pit. The author also noticed the occurrence of a flint implement of the type of those of St. Acheul in a gravel near Downton in Hampshire. This gravel capped a small chalk-pit, and its elevation above the River Avon was about I 50 feet. Two gravel terraces occur between this pit and the river, one 40 by 60 the other 80 by 1 I 0 feet above the level of the latter. Mr. Codrington stated that, according to the Ordnance Survey, the level of the pit at Cams Wood was not more than roo feet above the sea, so that it was at about the same level as the gravels of Titchfield and elsewhere. Mr. Evans remarked that the flint flake from Cams Wood presented no characters such as would prove it to be of Palaolithic age. He was, on the contrary, inclined to regard it as having been derived from the surface. He commented on the height at which the Downton implement had been discovered, which was, however, not so great but that the containing gravels might be of fluviatile origin Mr. Gwyn Jeffreys thought that if the beds at Cams Wood were marine, some testaceous remains might be found in them. If these were absent, he should rather be inclined to regard them as fluviatile. Mr. J. W. Flower contended that the gravel at Downton could not be of fluviatile origin. He thought, indeed, that the gravel was actually at a higher level than the present source of the river. If this were so, he maintained that i he trans. port of the gravel by fluviatile action was impossible. He further observed that gravels precisely similar, also containing implements, had now been found, as well in the Hampshire area as elsewhere, the transport of which, in his view, could not possibly be attributed to any existing rivers. At Southampton they occur I 5 feet above the River Itchen and the sea, and considerably inland; at Bournemonth, on a sea cliff 120 feet in height; and at the Foreland (at the eastern extremity of the Isle of Wight), on a cliff 82 feet above the sea, and far remote from any river. If, therefore, these deposits were effected by fluviatile agency, it was evident that all traces of the rivers were afterwards effaced by some great geological changes, or, in the alternative, some great geological change, not fluviatile, must have caused the deposit. Upon the whole he was disposed to conclude with the French geologists as well as with many eminent English authors that the accumulation of all these superficial drifis was, as the late Sir Roderick Murchison had said, sudden and tumultuous, not of long continuance; and thus it was such as wonld result from some kind of diluvial action, rather than from the ordinary long-continued action of water. Mr. Judd pointed ont, in coniravention to Mr. Jeffreys' views, that in the Fen district, over large tracts of deposits of undoubtedly marine origin, not a trace of marine shells cou!d be found. Mr. Prestwich, while willing to concede that the implement-bearing gravel-beds had been deposited un ler more tumultunus action than that due to rivers of the present day, was still forced to attribute the excavation of the existing valleys and the formation of terraces along their slopes to river-action. He showed that Mr. Flower's argument as to the present level of the source of the river was of no weight, as the country in which it had its source was formerly, as now, at a much higher level than the gravel at Downton. As to the absence of marine shells at Cams Wood, he cited a raised beach in Cornwall which, in company with Mr. Jeffreys, he had examined for a mile without finding a trace of a shell, though for the next. half-mile they abounded. There was the same d fference between the raised beach at Brighton and at Chichester. He was obliged to $\mathrm{Mr}$. Codrington for his correction as to the level at Cains Wood, though the pit was at a higher elevation than the one to which Mr. Codrington had alluded.-2. "On some undescribed Fossils from the "Menevian Group of Wales." By Mr. H. Hicks. In 